\title{
Stripe of normal mechanisms for crustal earthquakes with $M \leq 3.5$ flanking the western side of the thrust front zone in the Andes backarc
}

\author{
Silvina Nacif ${ }^{1^{*}}$, Enrique Triep $^{2}$, Renzo Furlani ${ }^{2}$, Silvana Spagnotto $^{3}$ \\ ${ }^{1}$ Fondo Argentino Sectorial, Agencia de Promoción Científica y Tecnológica, Godoy Cruz, Argentina; \\ *Corresponding Author: nacif.silvina@gmail.com \\ ${ }^{2}$ Instituto Geofísico Sismológico F. Volponi (IGSV), Facultad de Ciencias Exactas, Físicas y Naturales, Universidad Nacional de San \\ Juan, San Juan, Argentina \\ ${ }^{3}$ Consejo Nacional de Investigaciones Científicas y Técnicas, Universidad Nacional de San Luis, San Luis, Argentina
}

Received 13 June 2013; revised 13 July 2013; accepted 20 July 2013

Copyright (C) 2013 Silvina Nacif et al. This is an open access article distributed under the Creative Commons Attribution License, which permits unrestricted use, distribution, and reproduction in any medium, provided the original work is properly cited.

\section{ABSTRACT}

Earthquakes with magnitudes $\mathrm{M} \leq 3.5$ were registered in the Andes backarc between $232.5^{\circ} \mathrm{S}$ $33.75^{\circ} \mathrm{S}$ within a temporary experiment from November 2002 to March 2003. Data were collected from 15 seismological broad band stations, deployed above flat subduction section and also above the transitional to normal section of the Nazca plate. Seismic events were located mostly in part of the Southern Precordillera and Cerrilladas Pedemontanas of Mendoza Province. Focal mechanism solutions were obtained, for selected data between $15 \mathrm{~km}$ and 35 km depths, from $P$ wave first motion using FOCMEC software. A band trending NW-NNW of normal focal mechanism earthquakes is located just by the thrust front towards West, and covers the Southern tip of the Southern Precordillera and the Western side of the Cerrilladas Pedemontanas, Mendoza Province, Argentina. Thrust focal mechanism solutions obtained in the present work for events with magnitude less than or equal to 3.5 also show that the thrust front South of $\sim 33.1^{\circ} \mathrm{S}$ is located in the same place as $M w \geq 3.6$ earthquakes. The most significant findings in this work are these signals of extensional regimen which appear in a compressional subduction tectonic regimen. Nevertheless the short temporal experiment precludes firm interpretations about this particular phenomenon. Probably it is related to a temporary stress relaxation. The normal earthquakes are likely associated to normal faults, and/or to their subsidiaries, that were inverted by con- traction and now re-inverted at least transitorily as normal. These faults, which are near and to the East of the suture between Chilenia and Cuyania Paleozoic terranes, were originally involved in the Cuyo Triassic basin formation.

Keywords: Small Magnitudes Seismicity; Normal Focal Mechanism Solutions; Normal Fault Activation; Regional Compressional Regime

\section{INTRODUCTION}

Seismological data from CHARSME (CHile ARgentina Seismological Measurement Experiment) Experiment (Figure 1), allowed us characterize the crustal seismicity with magnitude less than or equal to 3.5 . Crustal seismicity from earthquakes with $\mathrm{Mw}>3.5$ is widely known by INPRES (Instituto Nacional de PRevención Sísmica) and NEIC (National Earthquake Information Center). The major percent of focal mechanisms show normal solutions. In the region, focal mechanisms from earthquakes with magnitude greater than 3.6 were obtained from Harvard CMT Catalog, [1-5]. In Figure 2 some of them were plotted. Forward wave modeling [1] and Moment Tensor Inversion Techniques [3-5] returned in most cases, according to geological evidence $[6,7]$, thrust focal mechanism solutions (in some cases with a strike component).

Subduction process supplied compressive stress to the crust, principally in the East-West direction [8]. In fact, this explains the almost total dominance of observed thrust focal mechanisms ( $\mathrm{Mw} \geq 3.6)$.

The notable distinction in this work is the presence of small events with normal focal mechanism solutions. Clearly we have to inquire about the relationship of those 


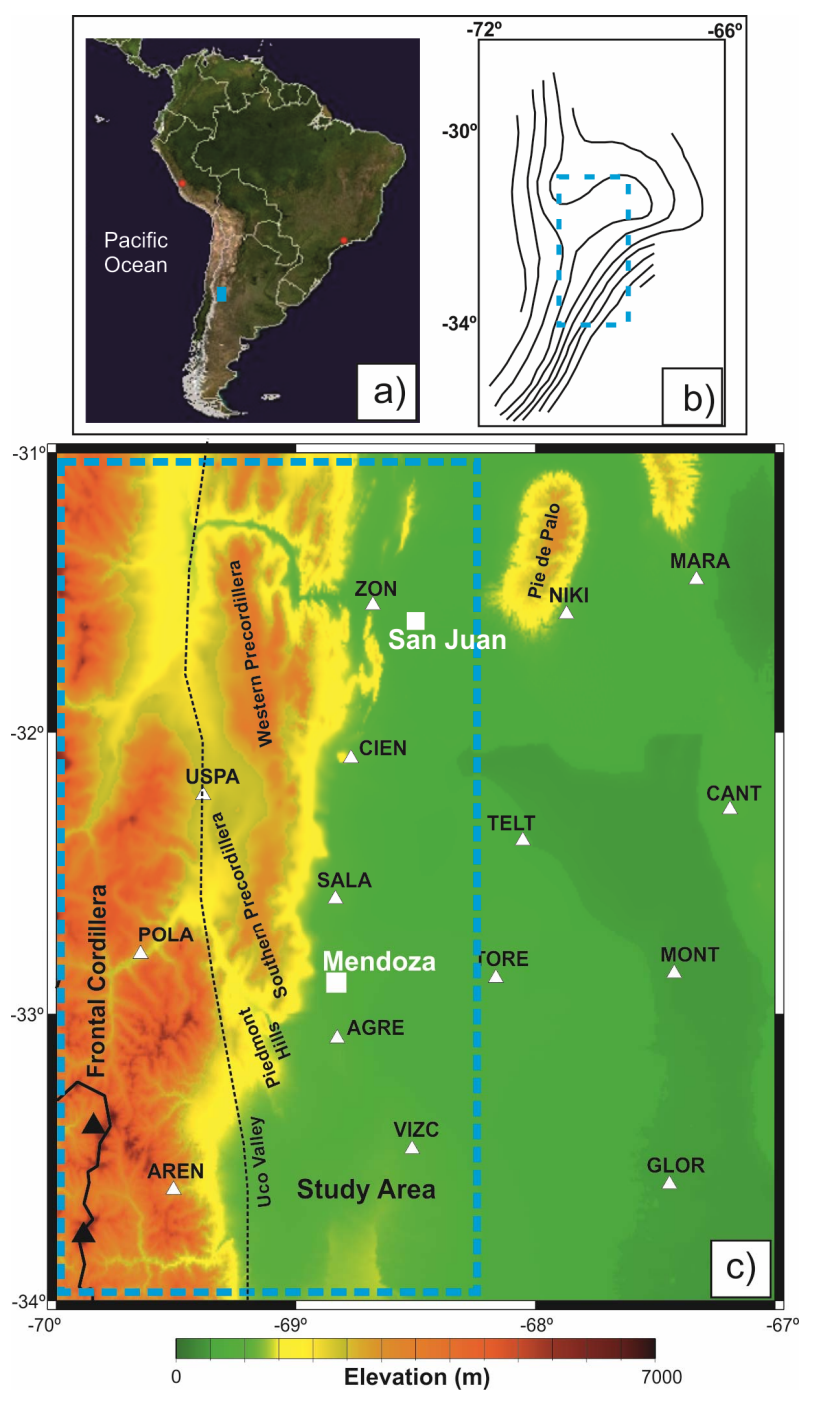

Figure 1. (a) Location map. (b) Contours of Wadati Benioff zone from [9], blue box: shows the study region. (c) CHARSME Experiment map. Blue frame: study region, white triangles: broad band stations, black triangles: active volcanoes, dotted thin black line: boundary between Chilenia and Cuyania terranes [16].

different size earthquakes to the compressional dominant stress pattern.

\section{TECTONIC SETTING}

The region under study is situated above the Nazca flat subduction section and also above the transitional section to normal subduction section South of $\sim 33.5^{\circ} \mathrm{S}$ [9].

Flat subduction in the North of $33^{\circ} \mathrm{S}$ relates with the absence of Cenozoic volcanism [10] and with the morpho-structure units of Principal, Frontal and Pre-Cordillera, and with Pampean Sierras. This flat subduction is explained by Juan Fernandez Ridge subduction [11] supported by results in [12], which control Quaternary volcanism absence and high contractional backarc tec- tonics [13]. South of $33^{\circ} \mathrm{S}$, with deepening subduction, the reduction of maximum heights of Principal and Frontal Cordillera is observable.

Another feature at this latitude is the progressive disappearance of Precordillera and Sierras Pampeanas. The active arc volcanism appears in this same latitude (volcanoes: Tupungatito, Marmolejo San Jose and Maipo) [14].

The basement of the study region suffered a complex history of collisions and accretions during Late Proterozoic and Early Paleozoic [15]. The boundaries between the different terranes exert a high control in the Andean Tectonic [15]. Chilenia terrane constitutes Andes basement and Cuyania composite terrane makes up Precordillera and Pie de Palo basement [16]. The region studied includes Frontal Cordillera, Precordillera, and Piedmont Hills.

\section{DATA AND METHODOLOGY}

The CHARSME Experiment financed by Chilean CONICYT was a project of scientific cooperation between the DRO team UMR Géoazur (France), UR082 the IRD (France), Department of Geophysics of the University of Chile (Santiago, Chile) and the Geophysics Seismological F. Volponi Institute, University of San Juan (Argentina). The experiment deployed seismological stations from $31^{\circ} \mathrm{S}$ to $34.5^{\circ} \mathrm{S}$ and $67^{\circ} \mathrm{W}$ to $72^{\circ} \mathrm{W}$ from November 2002 to March 2003. Data used in this work came from the 15 broad band stations located in Argentina (Figure 1). Even though data are from an Experiment conducted 10 years ago, there is no work which refers to these seismic events. On the other hand, results show a phenomenon not observed before in the study region.

Hypocenter [17] was used to locate seismicity (Figures 3 and 4), it is iterative software written in Fortran 77. The software finds location parameters for single events from a set of arrival times. In most cases $\mathrm{P}$ and $\mathrm{S}$ arrival times were available. A Flowchart showing the main steps is available in [17]. Confidence regions were computed for events of Table 1, in all cases the semi-major axis of the $90 \%$ confidence region was less than $\sim 6 \mathrm{~km}$ (Figure 4). For the crustal structure we used the one-dimensional velocity model from [18], obtained for the study region.

We found focal mechanisms solutions from $\mathrm{P}$ first motion using FOCMEC [19]. This traditional methodology was used instead of Moment Tensor Inversion techniques e.g. [20], considering seismic records from small earthquakes are highly influenced by the cortical structure below the stations. Unless the velocity model has well known is very difficult find focal mechanism solutions from Moment Tensor Inversion for events with magnitude less than 4.0 [20]. We used the Aki and Richards convention [21] for nodal planes parameters (strike, dip, rake). These parameters were varied at a constant angle of $5^{\circ}$ to perform the search of focal sphere consistent 


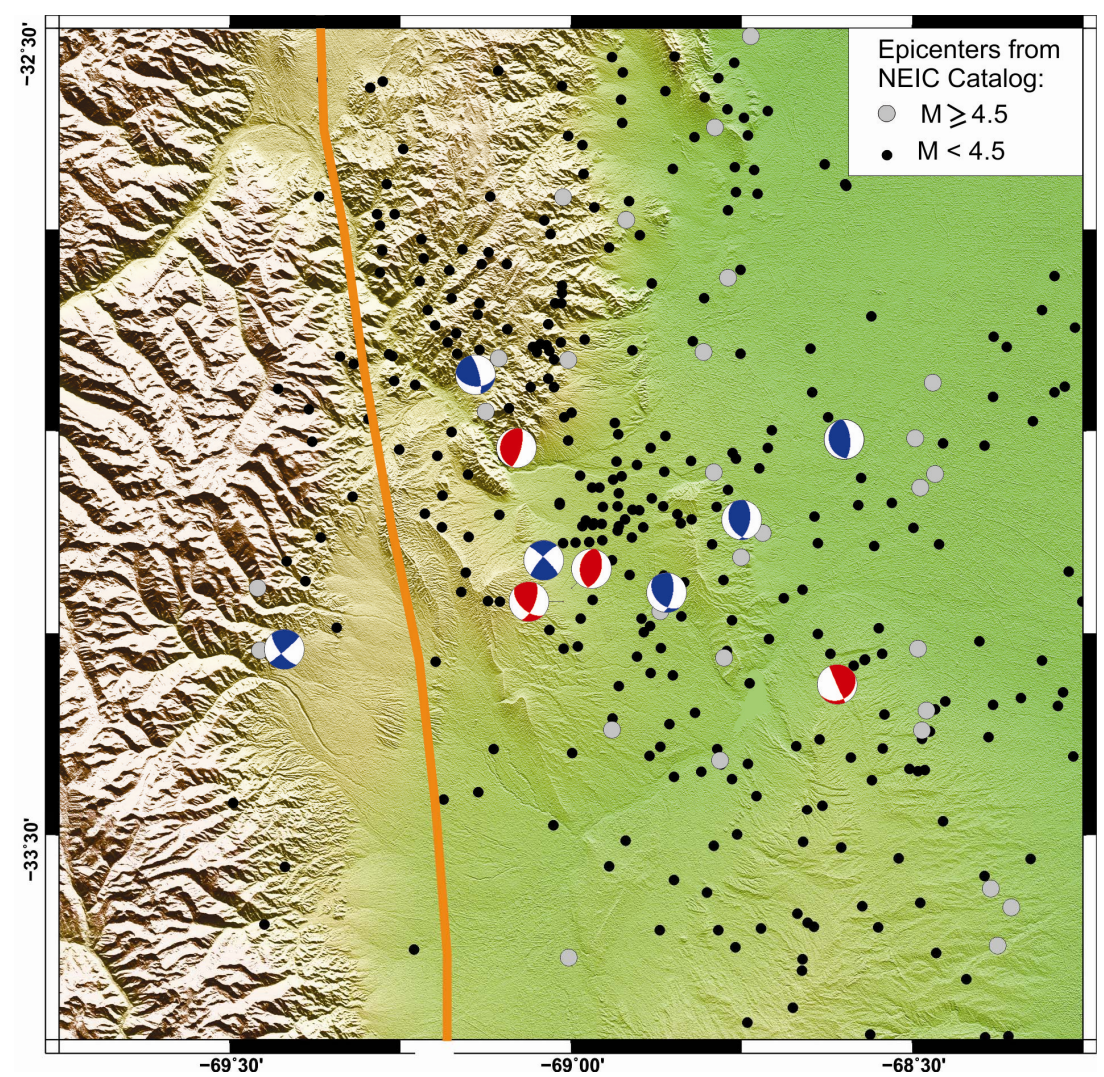

Figure 2. Seismicity of NEIC Catalog (USGS) from May-1973 to June-2013. Focal Mechanism Solutions (Double Cupla part of Moment Tensor) from: CMT-Harvard in blue color (4.8 $\left.\leq \mathrm{M}_{\mathrm{w}} \leq 5.9\right)$ and from [3] in red color (3.6 $\left.\leq \mathrm{M}_{\mathrm{w}} \leq 4.7\right)$. Orange line: boundary between Chilenia and Cuyania terranes [16].

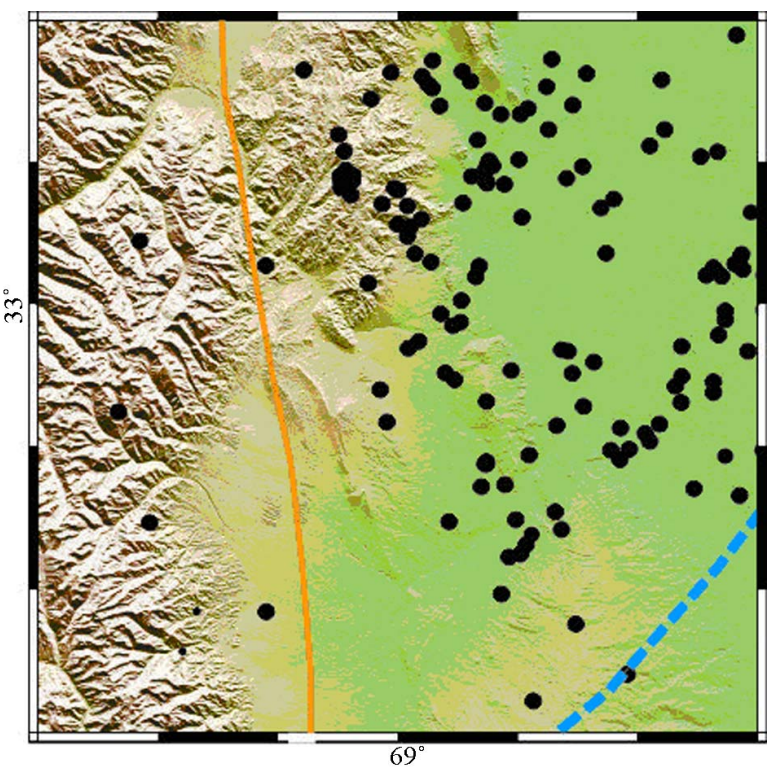

Figure 3. Located seismicity using hypocenter [17] from the experiment period. This figure does no show the epicenters from seismicity used to obtain focal mechanism solutions. Blue dashed line shows the deformation thrust front proposed in this work. Orange line: Boundary between Chilenia and Cuyania terranes [16]. with the P first motion distribution. The excellent station coverage (most cases Azimuthal Gap $<90^{\circ}$ ) yields a reliable estimate of fault plane solution. The major source of errors came from uncertainties in first movement reading. We considered impulsive and emergent movement when the first motion was read. Acceptable solutions were those which have at least 8 readings and only one inconsistency in the polarity.

\section{RESULTS}

Seismicity registered in $\sim 4$ months shows similar pattern to the NEIC USGS Catalog (for comparation see Figures 2-4). Seismicity is mainly located in South Precordillera [22], East of Uco Valley and on the foothill of Frontal Cordillera (Figures 3 and 4). The magnitude duration scale was not calibrated for the study region so we did not obtain realistic magnitudes for these events. Nevertheless comparison of four events (studied here) registered from NEIC Catalog (USGS) permit to infer that all magnitudes are less equal than 3.5. At least readings from 8 stations were necessary for acceptable focal mechanism solutions (Table 1). A quality classification was applied to the focal mechanism solutions 


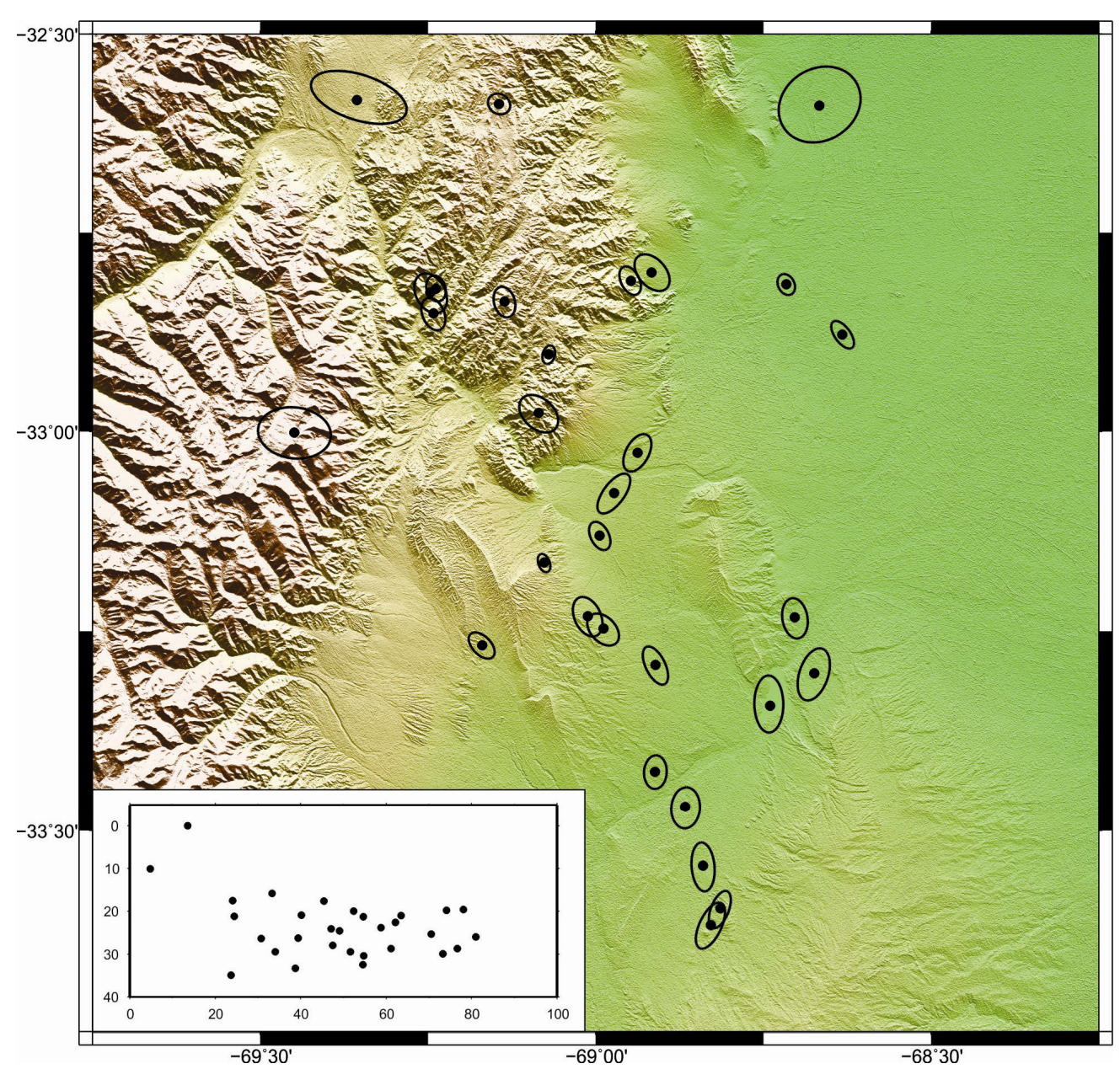

Figure 4. Hypocenters were plotted for seismicity with available focal mechanism solutions obtained in this work these are showed by black circles. Events 17, 18, 23 and 34 located to the North of $32.5^{\circ} \mathrm{S}$ were not plotted for clarity figure (indicated by asterisk in Table 1). Ellipses errors were plotted for each events (obtained for $90 \%$ of confidence region). Inset cross section: events were project on an East-West plane. Note that in general events are between depths 15 and $35 \mathrm{~km}$.

considering the family solutions behavior, i.e. strike and dip variation within the family solutions for each event. Strike and dip maximum variation less than $25^{\circ}, 30^{\circ}$ and $40^{\circ}$ correspond to Very Well (VW), Well (W) and Regular (R) quality, respectively (Table 1). In all cases, the errors have not changed the compressional or dilatational character of the mechanism. Type mechanism classification (Table 1) was obtained with the same procedure as in [23]. This method is based on the plunge calculation of null (B), pressure (P) and tensional $(\mathrm{T})$ axes. The nomenclature are $\mathrm{TH}$, thrust; NO, normal; SS, strike-slip; TS, thrust with a strike-slip component; NS, normal with a strike-slip component strike-slip component; ST, strike-slip with a thrust component; SN, strike-slip with a normal component. Focal mechanism solutions from 34 seismic events (Figure 5 and Table 1) show dominantly normal solutions (20 normal, 11 thrust and 3 strike).

\section{DISCUSSION}

The seismicity showed in the present work, between $32.5^{\circ} \mathrm{S}$ and $33.75^{\circ} \mathrm{S}$ in the backarc of the Andes, is mainly related to two morphotectonic units (Figures 3 and 4), part of the Southern Precordillera [22] and Cerrilladas Pedemontanas of Mendoza Province, Argentina. The area shows focused Quaternary deformation, in [6] and [24], and most of it pertains to the thrust front (blue dashed line in Figure 3). A regional NW trending neotectonic structure (see blue line in Figure 5), the Río de Mendoza-Tupungato strip [6] mainly includes the Cordillera Frontal Eastern part between $32.75^{\circ} \mathrm{S}$ and $33.15^{\circ} \mathrm{S}$, and to the South the Cerrilladas Pedemontanas occidental branch (Figure 5). The structure has resulted from the interference of the Late Cenozoic Andean deformation with NW-trending rift structure of the Triassic Cuyo ba$\sin [6]$. 
Table 1. Focal mechanism solutions obtained from P first motion using FOCMEC [19] software. Equal area projection of inferior hemisphere was used. We made use of Aki and Richards convention [23] for focal mechanism solutions. Nodal planes were defined by: $0^{\circ} \leq$ strike $\leq 360^{\circ}, 0^{\circ} \leq \operatorname{dip} \leq 90^{\circ}$ and $-180^{\circ} \leq \operatorname{rake} \leq 180^{\circ}$ (Thrust Fault: $0^{\circ}<$ rake $<180^{\circ}$ and Normal Fault: $-180^{\circ}<$ rake $<0^{\circ}$ ). Values of strike, dip and rake for each event shown in this work was the selected focal mechanism solution between a family of solutions.

\begin{tabular}{|c|c|c|c|c|c|c|c|c|c|c|c|}
\hline \multirow[t]{2}{*}{ ID } & \multirow{2}{*}{$\begin{array}{c}\text { Date } \\
\text { yr/ } \\
\text { mon./ } \\
\text { day }\end{array}$} & \multirow{2}{*}{$\begin{array}{c}\begin{array}{c}\text { GMT Origin } \\
\text { time }\end{array} \\
\mathrm{hh}: \\
\mathrm{mm}: \\
\mathrm{ss}\end{array}$} & \multirow{2}{*}{$\begin{array}{c}\text { Lat. } \\
\begin{array}{l}\text { Grade } \\
\text { minute }\end{array}\end{array}$} & \multirow{2}{*}{$\begin{array}{l}\text { Long. } \\
\begin{array}{l}\text { grade } \\
\text { minute }\end{array}\end{array}$} & \multirow{2}{*}{$\begin{array}{c}\text { Dep. } \\
\mathrm{km}\end{array}$} & \multirow{2}{*}{$\begin{array}{c}\text { Dep. } \\
\text { Error }\end{array}$} & \multicolumn{3}{|c|}{$\begin{array}{l}\text { Focal Mechanism } \\
\text { Solution }\end{array}$} & \multirow[t]{2}{*}{ Type } & \multirow[t]{2}{*}{ Qt. } \\
\hline & & & & & & & Strike & $\begin{array}{l}\text { Dip } \\
\text { grade }\end{array}$ & Rake & & \\
\hline 1 & $\begin{array}{l}02 / \\
11 / \\
26\end{array}$ & $\begin{array}{c}21: \\
24: \\
50.81\end{array}$ & $\begin{array}{c}-32 \\
48.64\end{array}$ & $\begin{array}{c}-68 \\
56.84\end{array}$ & 29.5 & 7.3 & $\begin{array}{c}258.7 \\
98\end{array}$ & $\begin{array}{l}75.1 \\
15.8\end{array}$ & $\begin{array}{c}84.8 \\
108.7\end{array}$ & $\mathrm{TH}$ & VW \\
\hline 2 & $\begin{array}{l}02 / \\
11 / \\
28\end{array}$ & $\begin{array}{c}16: \\
20: \\
51.54\end{array}$ & $\begin{array}{c}-32 \\
34.99\end{array}$ & $\begin{array}{c}-69 \\
21.34\end{array}$ & 0.0 & 8.6 & $\begin{array}{c}259.3 \\
16.2\end{array}$ & $\begin{array}{l}65.8 \\
44.8\end{array}$ & $\begin{array}{c}-51 \\
-144.5\end{array}$ & NS & VW \\
\hline 3 & $\begin{array}{l}02 / \\
12 / \\
06\end{array}$ & $\begin{array}{c}01: \\
03: \\
04.97\end{array}$ & $\begin{array}{c}-32 \\
35.26\end{array}$ & $\begin{array}{l}-69 \\
8.65\end{array}$ & 15.8 & 5.5 & $\begin{array}{c}254.9 \\
28.6\end{array}$ & $\begin{array}{c}54.4 \\
46\end{array}$ & $\begin{array}{l}-58.7 \\
-126\end{array}$ & NO & W \\
\hline 4 & $\begin{array}{l}02 / \\
12 / \\
07\end{array}$ & $\begin{array}{c}21: \\
02: \\
53.14\end{array}$ & $\begin{array}{c}-33 \\
28.17\end{array}$ & $\begin{array}{c}-68 \\
51.98\end{array}$ & 23.8 & 4.0 & $\begin{array}{c}337 \\
176.3\end{array}$ & $\begin{array}{l}15.8 \\
75.1\end{array}$ & $\begin{array}{l}71.3 \\
95.2\end{array}$ & $\mathrm{TH}$ & $\mathrm{R}$ \\
\hline 5 & $\begin{array}{l}02 / \\
12 / \\
10\end{array}$ & $\begin{array}{c}\text { 05: } \\
08: \\
00.40\end{array}$ & $\begin{array}{c}-33 \\
16.04\end{array}$ & $\begin{array}{c}-69 \\
10.17\end{array}$ & 26.4 & 2.7 & $\begin{array}{l}220 \\
352\end{array}$ & $\begin{array}{l}75.5 \\
21.1\end{array}$ & $\begin{array}{l}-74.5 \\
-136\end{array}$ & NO & W \\
\hline 6 & $\begin{array}{l}02 / \\
12 / \\
12\end{array}$ & $\begin{array}{c}04: \\
17: \\
27.70\end{array}$ & $\begin{array}{c}-33 \\
13.96\end{array}$ & $\begin{array}{c}-68 \\
42.18\end{array}$ & 19.8 & 3.8 & $\begin{array}{l}338.2 \\
236.9\end{array}$ & $\begin{array}{l}66.1 \\
66.1\end{array}$ & $\begin{array}{c}26.3 \\
153.6\end{array}$ & ST & W \\
\hline 7 & $\begin{array}{l}02 / \\
12 / \\
17\end{array}$ & $\begin{array}{c}14: \\
59: \\
35.44\end{array}$ & $\begin{array}{c}-33 \\
13.88\end{array}$ & $\begin{array}{l}-69 \\
0.70\end{array}$ & 17.6 & 4.4 & $\begin{array}{c}286.6 \\
77.5\end{array}$ & $\begin{array}{l}22.3 \\
70.3\end{array}$ & $\begin{array}{c}-62.7 \\
-100.6\end{array}$ & NO & $\mathrm{R}$ \\
\hline 8 & $\begin{array}{l}02 / \\
12 / \\
19\end{array}$ & $\begin{array}{c}02: \\
13: \\
44.88\end{array}$ & $\begin{array}{l}-33 \\
9.84\end{array}$ & $\begin{array}{l}-69 \\
4.60\end{array}$ & 26.3 & 1.9 & $\begin{array}{l}205 \\
25\end{array}$ & $\begin{array}{l}65 \\
25\end{array}$ & $\begin{array}{l}-90 \\
-90\end{array}$ & NO & VW \\
\hline 9 & $\begin{array}{l}02 / \\
12 / \\
22\end{array}$ & $\begin{array}{c}01: \\
42: \\
15.72\end{array}$ & $\begin{array}{c}-32 \\
50.22\end{array}$ & $\begin{array}{l}-69 \\
8.13\end{array}$ & 29.5 & 5.1 & $\begin{array}{c}239.2 \\
0.8\end{array}$ & $\begin{array}{c}80.3 \\
18\end{array}$ & $\begin{array}{l}-74.8 \\
-147\end{array}$ & NO & VW \\
\hline 10 & $\begin{array}{l}02 / \\
12 / \\
23\end{array}$ & $\begin{array}{c}13: \\
50: \\
12.80\end{array}$ & $\begin{array}{c}-32 \\
49.22\end{array}$ & $\begin{array}{c}-69 \\
14.28\end{array}$ & 21.2 & 4.0 & $\begin{array}{c}335.1 \\
77.7\end{array}$ & $\begin{array}{l}20.6 \\
85.3\end{array}$ & $\begin{array}{c}-13.5 \\
-110.1\end{array}$ & NO & VW \\
\hline 11 & $\begin{array}{l}02 / \\
12 / \\
24\end{array}$ & $\begin{array}{c}10: \\
10: \\
15.92\end{array}$ & $\begin{array}{l}-33 \\
0.09\end{array}$ & $\begin{array}{c}-69 \\
26.94\end{array}$ & 10.1 & 10.8 & $\begin{array}{c}322.4 \\
79.3\end{array}$ & $\begin{array}{l}44.8 \\
65.8\end{array}$ & $\begin{array}{c}-35.5 \\
-128.9\end{array}$ & NS & VW \\
\hline 12 & $\begin{array}{l}02 / \\
12 / \\
25\end{array}$ & $\begin{array}{c}08: \\
31: \\
33.85\end{array}$ & $\begin{array}{c}-32 \\
54.17\end{array}$ & $\begin{array}{l}-69 \\
4.21\end{array}$ & 20.9 & 2.4 & $\begin{array}{l}113.5 \\
278.2\end{array}$ & $\begin{array}{l}20.6 \\
70.1\end{array}$ & $\begin{array}{l}-75.6 \\
-95.3\end{array}$ & NO & VW \\
\hline 13 & $\begin{array}{l}02 / \\
12 / \\
30\end{array}$ & $\begin{array}{c}13: \\
29: \\
18.58\end{array}$ & $\begin{array}{l}-33 \\
1.58\end{array}$ & $\begin{array}{c}-68 \\
56.25\end{array}$ & 20.0 & 3.0 & $\begin{array}{c}260.7 \\
22.7\end{array}$ & $\begin{array}{l}71.9 \\
31.6\end{array}$ & $\begin{array}{l}-63.6 \\
-143.7\end{array}$ & $\mathrm{NO}$ & VW \\
\hline 14 & $\begin{array}{l}02 / \\
12 / \\
31\end{array}$ & $\begin{array}{c}04: \\
28: \\
07.65\end{array}$ & $\begin{array}{l}-33 \\
4.61\end{array}$ & $\begin{array}{c}-68 \\
58.36\end{array}$ & 24.6 & 2.9 & $\begin{array}{l}309.3 \\
167.1\end{array}$ & $\begin{array}{l}48.4 \\
48.4\end{array}$ & $\begin{array}{c}62.8 \\
117.2\end{array}$ & $\mathrm{TH}$ & VW \\
\hline 15 & $\begin{array}{l}03 / \\
01 / \\
02\end{array}$ & $\begin{array}{c}03: \\
18: \\
50.54\end{array}$ & $\begin{array}{c}-33 \\
37.04\end{array}$ & $\begin{array}{c}-68 \\
49.71\end{array}$ & 22.6 & 2.5 & $\begin{array}{l}116.6 \\
258.4\end{array}$ & $\begin{array}{l}52.8 \\
43.9\end{array}$ & $\begin{array}{c}-64.6 \\
-119.5\end{array}$ & NO & VW \\
\hline 16 & $\begin{array}{l}03 / \\
01 / \\
02\end{array}$ & $\begin{array}{c}\text { 06: } \\
\text { 13: } \\
43.08\end{array}$ & $\begin{array}{c}-33 \\
35.82\end{array}$ & $\begin{array}{c}-68 \\
48.87\end{array}$ & 21.0 & 2.5 & $\begin{array}{c}32.9 \\
201.4\end{array}$ & $\begin{array}{l}60.1 \\
30.4\end{array}$ & $\begin{array}{l}-84.2 \\
-100\end{array}$ & NO & VW \\
\hline $17^{*}$ & $\begin{array}{c}03 / \\
01 / \\
03\end{array}$ & $\begin{array}{c}09: \\
36: \\
11.02\end{array}$ & $\begin{array}{c}-31 \\
55.82\end{array}$ & $\begin{array}{c}-69 \\
10.37\end{array}$ & 30.1 & 6.8 & $\begin{array}{l}117.1 \\
286.5\end{array}$ & $\begin{array}{l}35.3 \\
55.1\end{array}$ & $\begin{array}{l}-81.3 \\
-96.1\end{array}$ & NO & W \\
\hline $18^{*}$ & $\begin{array}{c}03 / \\
01 / \\
10\end{array}$ & $\begin{array}{c}00: \\
44: \\
26.05\end{array}$ & $\begin{array}{c}-31 \\
45.33\end{array}$ & $\begin{array}{c}-69 \\
34.23\end{array}$ & 10.0 & 15.3 & $\begin{array}{c}220 \\
40\end{array}$ & $\begin{array}{l}50 \\
40\end{array}$ & $\begin{array}{l}-90 \\
-90\end{array}$ & NO & W \\
\hline 19 & $\begin{array}{l}03 / \\
01 / \\
12\end{array}$ & $\begin{array}{c}08: \\
20: \\
58.99 \\
\end{array}$ & $\begin{array}{c}-33 \\
25.53\end{array}$ & $\begin{array}{c}-68 \\
54.69\end{array}$ & 21.3 & 3.6 & $\begin{array}{l}285.9 \\
195.8\end{array}$ & $\begin{array}{c}50 \\
89.9\end{array}$ & $\begin{array}{c}0 \\
140\end{array}$ & ST & $\mathrm{R}$ \\
\hline
\end{tabular}




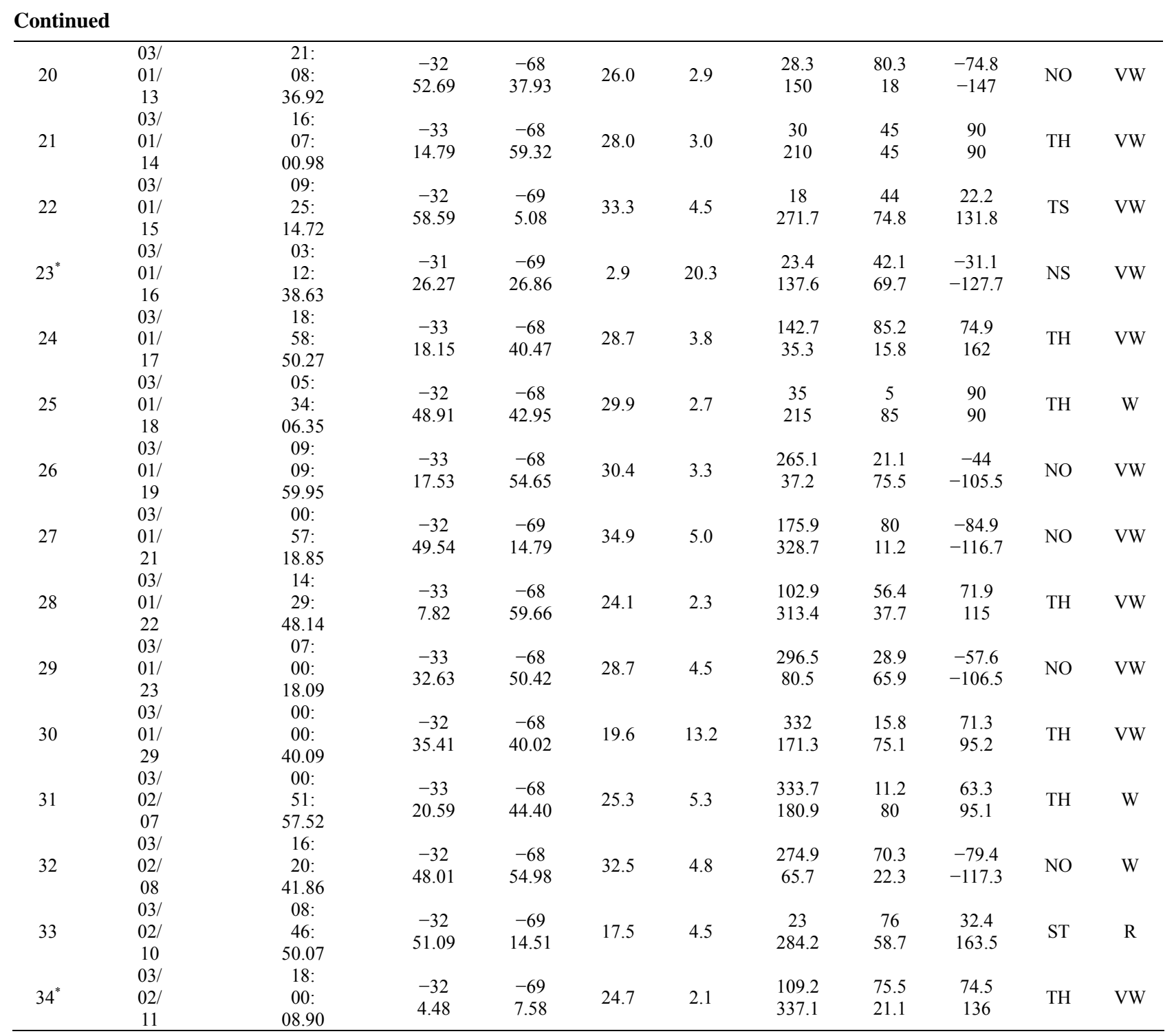

IN: Identification Number for the Events; Location Parameters: (Lat.: Latitude, Long.: Longitude, Dep.: Depth); Mc: Coda Magnitude; Location Depth Error: Dep. Error; Type of solutions: Type. TH, thrust; NO, normal; SS, strike-slip; TS, thrust with a strike-slip component; NS, normal with a thrust with a strike-slip component strike-slip component; ST, strike-slip with a thrust component; SN, strike-slip with a normal component. Quality of Solution: Qt. Very Well (VW), Well (W) and Regular (R).

The strip shows several different evidences of Quaternary tectonic activity. In the area, the Paleozoic suture between Chilenia and Cuyania is at the boundary between Cordillera frontal and Southern Precordillera, and towards West of the oriental border of the Cerrilladas Pedemontanas. This section of the suture also coincides with the Triassic basin oriental boundary [6,7]. The Southern Precordillera is characterized by high angle normal faults inverted by contraction and associated to faults trending NW and NNW and having a strike-slip component [6,7]. Tectonically inverted normal faults with the same orientation are also recognized within the Cerrilladas Pedemontanas [25].

Known focal mechanisms (Mw $\geq 3.6)$ from CMT Har- vard and from [3] are thrust except two that are strikeslip (Figure 2). The thrusts are located to the East of the Río Mendoza-Tupungato structure, except one for which the location error also permits to be placed to East of that structure. So, the active thrust front seems to be located to East of the Cerrilladas Pedemontanas occidental branch, which includes the Barrancas-LunluntaCarrizal anticlines.

Focal mechanisms obtained in the present work for M $\leq 3.5$ earthquakes (Figure 5) also show that the thrust front south of $\sim 33.1^{\circ} \mathrm{S}$ is located in the same place that for $\mathrm{Mw} \geq 3.6$ earthquakes. But, what is noticeable for those $\mathrm{M} \leq 3.5$ earthquakes is that just West of this area and in the Southern tip of the Southern Precordillera 


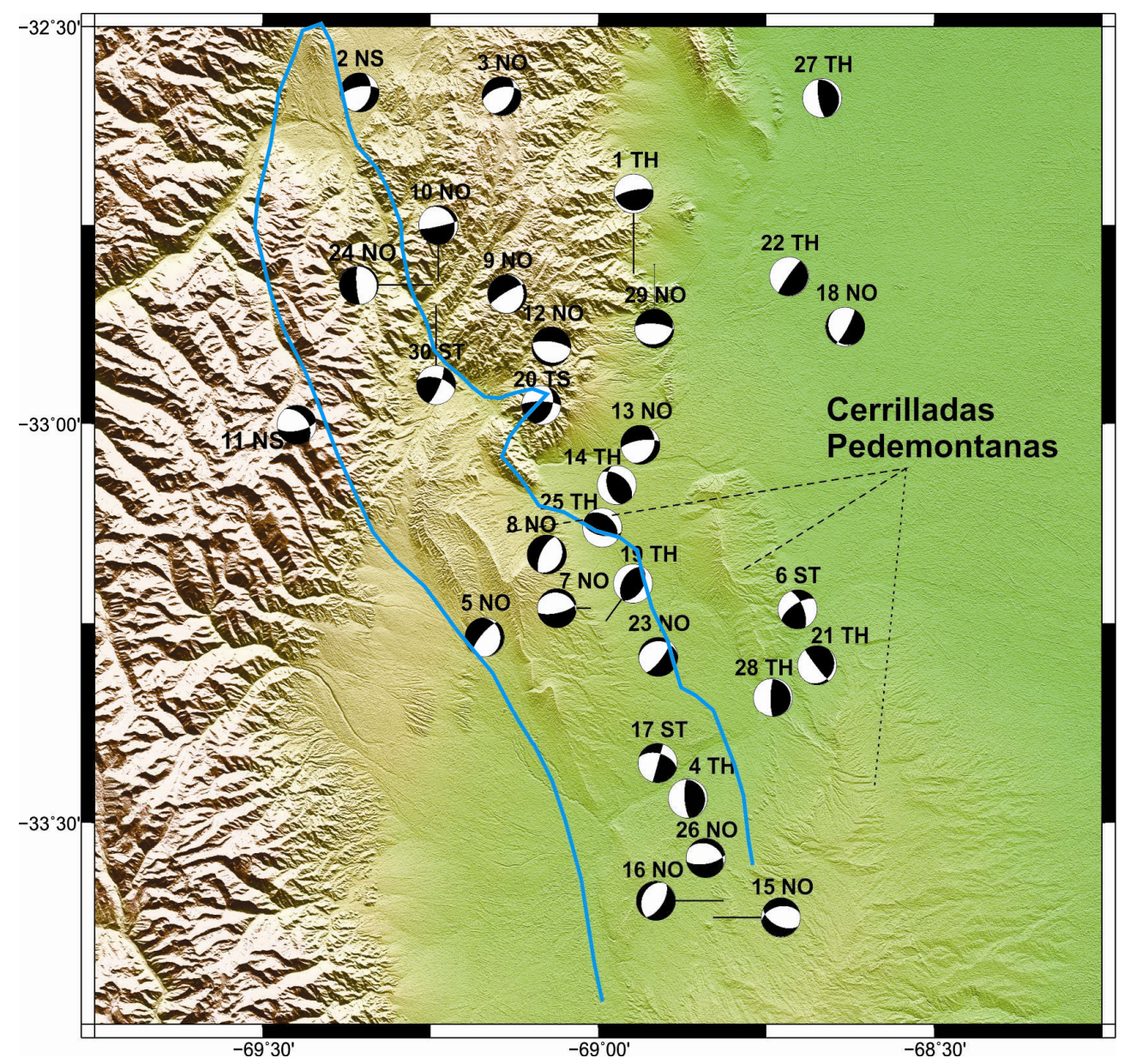

Figure 5. Focal mechanism solutions from Table 1 obtained from $P$ first motion. Number and Type are showed at the top of the mechanism. Extensional and compressional quadrants are in white and black color, respectively. For a clearer figure we did not plot 4 focal mechanism solutions North of $32.5^{\circ}$, three of them have normal solutions. Red dashed line marked - the North-Northwest fringe of normal focal mechanism solutions, this fringe extending to the north of $32.2^{\circ}$ (if we take account the 3 normal focal mechanisms not plotted here) and for longitude of $120 \mathrm{~km}$. Blue line: Río Mendoza-Tupungato Structure [6].

there is a fringe of normal focal mechanisms (from South to North, earthquakes number $16,23,5,7,8,13,11,12$, 9, 24, 10, 3 and 2, Figure 5 and Table 1) with the exception of an earthquake with strike-slip mechanism (number 30).

Since the data come from a temporary experiment of only four months, we do not know to what extends this behavior were transitory phenomena. This, because is inserted within a predominant compressional stress field. Some kind of regional stress relaxation might have being acting (at least at the time of the experiment) that produced those normal earthquakes.

We are not able to propose a consistent hypothesis to explain that probable relaxation. Weak hypothesis are some stress variation in the backarc related to subduction earthquake cycle, or even weaker the occurrence of a subduction slow earthquake (e.g. in [26]) that has not been documented to occur in any of the subducted Nazca plate sections.

\section{CONCLUSSIONS}

Data from a temporal experiment have revealed a narrow area about $120 \mathrm{~km}$ long trending NW-NNW with $\mathrm{Mw} \leq 3.5$ normal earthquakes. The area is located just to the West of the thrust front in the Cerrilladas Pedemontanas occidental branch and in the southern tip of the Southern Precordillera. The existence of those normal earthquakes in the Andes backarc within a predominant compressional field imposed by the subduction process is a puzzling phenomenon. Some kind of local and/or regional relaxation process must be acted to permit the normal mechanisms activation.

Nevertheless, whatever the relaxation process might be we can propose that the normal earthquakes with 
depths of 15 to $35 \mathrm{~km}$ (Figure 5) are likely to be associated to the mentioned inverted normal faults within the Southern Precordillera and the Cerrilladas Pedemontanas occidental branch. Those faults, or some of their subsidiaries, now re-inverted as normal (at least transitorily), are not exactly placed on the Chilenia-Cuyania suture but are related to Cuyo basin Triassic extension.

\section{REFERENCES}

[1] Chinn, D.S. and Isacks, B.L. (1983) Accurate source depths and focal mechanism of shallow earthquakes in western South America and New Hebrides Island Arc. Tectonics, 2, 529-563. doi:10.1029/TC002i006p00529

[2] Kadinsky-Cade, K. (1985) Seismotectonics of the Chilean margin and the 1977 Caucete Earthquake of western Argentina. Ph.D. Thesis, Cornell University, Ithaca, New York.

[3] Alvarado, P., Beck, S., Zandt, G., Araujo, M. and Triep, E. (2005) Crustal deformation in the south-central Andes backarc terranes as viewed from regional broad-band seismic waveform modelling, GJI. Seismology, 163, 580598. doi:10.1111/j.1365-246X.2005.02759.x

[4] Alvarado, P. and Beck, S., (2006) Source characterization of the San Juan (Argentina) crustal earthquakes of $15 \mathrm{Ja}-$ nuary 1944 (Mw 7.0) and 11 June 1952 (Mw 6.8). Earth and Planetary Science Letters, 243, 615-631. doi:10.1016/j.eps1.2006.01.015

[5] Alvarado, P., Beck, S. L. and Zandt, G. (2007) Crustal structure of the southcentral Andes Cordillera and backarc region from regional waveform modeling. Geophysical Journal International, 170, 858-875.

[6] Cortes, J., Casa, A., Pasini, M., Yamin, M. and Terrizzano, C. (2006) Fajas oblicuas de deformación neotectónica en

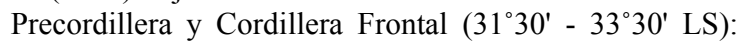
Controles Paleotectónicos. Revista de la Asociación Geológica Argentina, 61, 639-646.

[7] Giambiagi, L., Mescua, J., Bechis, F., Martínez, A. and Folguera, A. (2013) Pre-Andean deformation of the Precordillera southern sector, southern Central Andes. Geosphere, 7, 219-239. doi:10.1130/GES00572.1

[8] Brooks, B., Bevis, M., Smalley, R., Kendrick, E., Manceda, R., Lauria, E., Maturana, R. and Araujo, M. (2003) Crustal motion in the Southern Andes $\left(26^{\circ}-36 \mathrm{~S}^{\circ}\right)$ : Do the Andes behave like a microplate? Geochesmitry Geophysics Geosystems, 4, 1085. doi:10.1029/2003GC000505

[9] Anderson, M.L., Alvarado P., Zandt G. and Beck S. (2007) Geometry and brittle deformation of the subducting Nazca Plate Central Chile and Argentina. Geophysical Journal International, 171, 419-434. doi:10.1111/j.1365-246X.2007.03483.x

[10] Barazangi, M. and Isacks, B.L. (1976) Spatial distribution of earthquakes and subduction of the Nazca plate beneath South America. Geology, 4, 686-692. doi:10.1130/0091-7613(1976)4<686:SDOEAS >2.0.CO;2

[11] Yañez, G., Ranero, G. R., von Huene, R. and Díaz, J.,
(2001) Magnetic anomaly interpretation across a segment of the Sourthern Central Andes $\left(32^{\circ}-34^{\circ}\right)$ : Implications on the role of the Juan Fernández Ridge in the tectonic evolution of the margin during the upper Tertiary. Journal of Geophysical Research, 106, 6325-6345.

[12] Gans, C., Beck, S., Zandt, G., Gilbert, H. and Alvarado, P. (2011) Continental and oceanic crustal structure of the Pampean flat slab region, western Argentina, using receiver function analysis: New high-resolution results. Geophysical Journal International, 186, 45-58. doi:10.1111/j.1365-246X.2011.05023.x

[13] Allmendinger, R., Figueroa, D., Zinder, D., Beer, J., Mpodozis, C. and Isacks, B. L. (1990) Foreland shortening and crustal balancing in the Andes at $30^{\circ}$ latitude. Tectonics, 9, 789-809. doi:10.1029/TC009i004p00789

[14] Kay, S., Godoy, E. and Kurtz, A. (2005) Episodic arc migration, crustal thickening, subduction erosion, and magmatism in the south-central Andes. Geological Society of America Bulletin, 117, 67-88. doi:10.1130/B25431.1

[15] Ramos, V., Dallmeyer, R. D. and Vujovich, G. (1998) Time constraints on the Early Paleozoic docking of the Precordillera, central Argentina. Special Publications, 142, 143-158. doi:10.1144/GSL.SP.1998.142.01.08

[16] Ramos, V.A. (2004) Cuyania, an exotic block to Gondwana: Review of a historical success and the present problems: Gondwana Research, 7, 1009-1026. doi:10.1016/S1342-937X(05)71081-9

[17] Liener, B.R. and Havskov, J. (1995) A computer program for locating earthquakes locally, regionally and globally. Seismological Research Letters, 66, 26-36. doi:10.1785/gssrl.66.5.26

[18] Furlani, R. and Triep, E. (2007) Modelo mínimo de velocidades de ondas $\mathrm{P}$ y ondas $\mathrm{S}$ por encima de la transición de plana a normal de placa de Nazca entre latitudes $31.5^{\circ}-33.5^{\circ} \mathrm{S}$ y longitudes $67^{\circ}-70^{\circ}$. 17th Congreso Geológico Argentino, Jujuy, 7 al 10 de Octubre del 2008.

[19] Snoke, J.A., Munsey, J.W., Teague, A.C. and Bollinger, G.A. (1984) A program for focal mechanism determination by combined use of polarity and SV-P amplitude ratio data. Earthquakes Notes, 55, 3-15.

[20] Sokos, E. N. and Zahradnik, J. (2008) ISOLA a FORTRAN code and a Matlab GUI to perform multiple-point source inversion of seismic data. Computers \& Geosciences, 34, 967-977. doi:10.1016/j.cageo.2007.07.005

[21] Aki, K. and Richards, P. (1980) Quantitative seismology. Theory and methods. Volume I. W.H. Freeman, San Francisco.

[22] Cortés, J.M., Yamin, M.. and Pasini, M. (2005) La precordillera sur, provincias de mendoza y san juan. Actas del XVI Congreso Geológico Argentino, La Plata, 2005.

[23] www.ldeo.columbia.edu/seismology/triep/intra.expl.html

[24] Costa, C., Machette, M. N., Dart, R. L., Bastias, H. E., Paredes, J. D., Perucca, L. P., Tello, G. E. and Haller, K.M. (2000) Map and database of quaternary faults and folds in argentina. Open-File Report 00-0108, Department of the 
interior, United States Geological Survey, Reston.

[25] Ploszkiewicz, V. (1993) Yacimiento tupungato. Egeología y Recursos naturales de mendoza. $12^{\circ}$ Congreso Geológico Argentino y $2^{\circ}$ Congreso de Exploración de Hidrocarburos, Relatorio, Mendoza, 391-396.
[26] Kostoglodov V., Singh, S.K., Santiago, J.A., Franco, S.I., Larson, K.M., Lowry, A.R. and Bilham, R. (2003) A large silent earthquake in the Guerrero Seismic gap, Mexico. Geophysical Research Letters, 30, 1807. doi:10.1029/2003GL017219 